\title{
CENTRAL-EAST EUROPEAN EMPLOYEES ON THE LABOUR MARKET OF LONDON
}

\begin{abstract}
Purpose - The purpose of our exploratory research was to get acquainted with the sociodemographic characteristics, motivations, workplace conditions and social participation of foreign workers from different Central and Eastern European countries to London.

Design/methodology/approach - The survey was conducted as a questionnaire in London, in English and Hungarian. The sample $(\mathrm{n}=307)$ is based on individuals coming from different countries to London who are legally working. The pattern came through personal relationships. Examining the characteristics of the examined sample with descriptive statistics and the relationship between the examined quality variables were analysed by a Chi-square test. The investigation is primarily exploratory, but it also reveals some cause and effect relationships.

Findings - Our study gives an overview of the motivation, characteristics and integration of the Central-East European employees in England in a theoretical and empirical context and publishes the main findings of the examinations on integration. In general, it can be stated that social integration was achieved to a certain extent in the case of the examined sample. The research and analysis are justified by the globalisation of the labour market and the increasing transnational migration.

Research limitations/implications - The review aims at detail and thoroughness, but it is not complete. The findings at the end of the analysis are rather thought provoking, but we hope that we can also contribute to scientific and everyday discourse on migration.

Practical implications - The conclusions of the study provide an adequate framework for the development of a rational economic policy program, which is the basis for future development, for the conscious development of the future of our region.

Originality/Value - The novelty of the study lies in the composition of the sample on the one hand, and on the other hand, the study mainly focuses on the labour market. mobility.

Keywords: Central and Eastern European employees, integration, labour migration, geographic

Research type: research paper.

JEL classification:

J15 - Economics of Minorities, Races, Indigenous Peoples, and Immigrants; Non-labour Discrimination

J61 - Geographic Labor Mobility; Immigrant Workers

\footnotetext{
${ }^{1} \mathrm{PhD}$. associate professor, Szent István University, Faculty of Economics and Social Sciences, Gödöllő, Hungary, papp.imola@gtk.szie.hu

2 PhD. college professor, Eszterházy Károly University, Faculty of Economics and Social Sciences, Institute of Business Sciences, Gyöngyös, Hungary, bozsik.norbert@uni-eszterhazy.hu

3 PhD. associate professor, Szent István University, Faculty of Economics and Social Sciences, Gödöllő, Hungary, varga.erika@gtk.szie.hu
} 


\section{Introduction}

While West European countries are struggling with mass immigration of migrants and refugees, Central and Eastern Europe face the challenges of emigration. The well-trained young people who say good-bye to the eastern countries are leaving behind a weakening economy and a decreasing population.

The emigration crisis in the affected area was caused by stagnant post-communist economies and EU regulations that promote emigration. The single market does not mean economic growth and prosperity for all European states. As the borders opened for the countries joining the 2000s, the wave of labourers towards Germany, France and the United Kingdom began. The original idea that Central and Eastern Europe will attract investors due to their cheap wages, which will trigger economic growth, is hard to come to fruition. The findings at the end of the analysis are rather thought provoking, but we hope that we can also contribute to scientific and everyday discourse on migration.

\section{Theoretical background}

The approach of migration is inevitable from the side of various sociology theories (Sik, 2012). With regard to the motives of emigration, the Weberi typology is the determining factor of the target and the value-rational action. Rational action - as a motivation for employment abroad - has increased in modern society (Havrancsik, 2016). It is a goal-rational actor who chooses goals and selects from among the alternatives by taking into account the side effects, as well. On the other hand, in value-rational action, the side effects are underemphasized (Farkas, 2014).

In connection with the motivation of foreign employment, Murphy-Lejeune (2002) employs the concept of the so-called mobility capital. Accordingly, university students who have been studying or working while staying abroad (e.g. university student work) have a much greater and more self-confident willingness to work abroad. Based on the theory, geographical mobility causes students to acquire knowledge and behaviour patterns, develop skills and abilities that function as capital on the labour market. The ability to acquire mobility capital strongly relies on the economic and cultural capital of the individual (or his parents). This is confirmed by the analysis of Portes and Böröcz (1989). By examining the patterns of immigrants' settlements, it was found that the circumstances in which the emigrant country was abandoned, the status of migrants in the former (issuing country) and the reception skills in the country of destination, resulted in very different patterns of integration.

Motivation behind migration and the need to integrate as a consequence are complemented by Bourdieu's capital theory (human relationships also work as capitals). Social capital means belonging to a particular group, which has advantages and disadvantages. Group members can use their relationships to their own interests. Foreigners who can enter social communities and learn about and adopt the norms of the host country are more likely to have opportunities in the world of work (Awber, 2016; Havrancsik, 2016). Stone and Hughes (2002) recommend the operation of formal (group relationships, voluntary companies) and informal (family, friends, acquaintances) social networks to increase social capital. Informal networks are more important for immigrants, but some formal organizations also help integrate them.

After deciding and implementing migration, integration is the next difficulty. It is known that the utmost interest of the "outsider" (Schütz, 1984; Awake, 2008) is acquiring traditions consciously in a host group where no status exists for them. To be able to exist in the new environment, one must get acquainted with the natural and safe way of living of those who 
live there. According to Schütz the "alien" does not find new cultural patterns naturally, it is not easy to understand and even harder to apply them. The "success" of integration, for immigrants, also depends on which segment of the society or the labour market is integrated (Portes, Böröcz, 1989).

Emotional integration (a sense of belonging to the host society) can be approached from a phenomenological point of view, on the one hand, and from the honnethi recognition theory, on the other hand. While the former one is based on the subjective feelings of the people, the latter one emphasizes the experience of society. The recognition theory is based on the fact that in interpersonal relationships the unique qualities of the individual against others are to be estimated (Éber, 2016; Havrancsik, 2016). In Farkas's (2013) reading, this is geared towards respecting work performance. Recognizing the outcome of the job is the determinant of success in the labour market. The fundamental conflicts of modern society, according to Rózsa (2011), are based on "the individual experience of disenchantment and the relationship of disbelief and struggle for social recognition". Labour market integration is a starting point and a prerequisite for the social integration of migrants. "To understand the modern world, to find it home and, at the same time, to place ourselves, is a challenge that is inevitable for today's society and for each of its members" (Rózsa, 2011).

Finding a home is made easier by shortened travel time, easy to beat physical distances, and a reduction in travel-related burdens. The simple bridging of distances does not give you a feeling of secession, so the immigrant leaves the home environment that he can return at any time, and he does not have to face a permanent state of homelessness. Communication tools are accessible to everyone and the ability to contact at any time also relieves the feeling of secession. Individuals who stay for a long time in a distant physical-social-cultural space or multiple times from their home can become bound to both places. On the one hand, there is no need to interrupt their relations with the sending country and, on the other hand, their ties with the host country may also be established. This phenomenon is called by Bodó (2016) as a simultaneous embryo because the migrant does not have to "quit his roots"; in his absence he maintains relationships with the home, gets informed about his news and goes home to the special events. At the same time, he is present in the host society as well, living there "in the world", in an institutionalized form, in a controlled manner, enabling him to live "his alienate" in the form of complete rejection and deprivation.

\section{Labour market mobility nowadays}

For the citizens of East Central European countries, emigration and employment abroad became easier after the accession of the EU in 2004 and for Romania and Bulgaria in 2007. Previously, after complicated bureaucratic administration, it was only in the more prosperous Western countries that it was possible to work, so few of them were planning on the difficulties and the expenses involved. Even when entering the EU, foreign employment was not easier, as the old Member States could have kept restrictions for seven years. This was the case for the most important destination countries for Hungarian workers, as well. Germany, Austria and Switzerland were restricting the work of foreigners for the longest time, which barriers were only completely abolished in May 2011. In Sweden, Ireland and the United Kingdom, however, the labour market was opened at the time of accession in May 2004. In 2006, Finland, Greece, Iceland, Italy, Portugal and Spain, 2007 in the Netherlands and Luxembourg, France in 2008, Belgium, Denmark and Norway in 2009 allowed labour inflows (Andor, 2014). Language skills and cultural relations played an important role in which countries of the nation the citizens wanted to work in. The emigration of the Poles was mainly directed to England and Ireland. The Hungarians initially went to Germany and Austria. Most 
of them started work from Romania to Spain and Italy. Interesting economic changes have taken place in the decade since then.

Based on data from Eurostat (2016), $6.6 \%$ from the population of Poland,1.7 \% in the Czech Republic, 4.3 \% from Slovakia, $4.4 \%$ from Hungary, $14.1 \%$ from Romania and 9.7 per cent from Bulgaria live in Western Europe. In the case of Hungary, although emigration has begun slowly, data show the second largest growth in the last eight years. However, in comparison with other countries in the region, there is still a low proportion of expatriates (Hárs, 2016). According to the research conducted by the Hungarian Academy of Sciences, between 2011 and 2016 there was about 5 percent labour migration per year. The Romanian immigrant integration organization (Lazarescu (2015)). Of the countries of the European Union Romania has lost most of its population in the past decade, with 17 percent of their citizens leaving the country and Poland is the second in terms of the dynamics of emigration after Syria as it was pointed out by Lazarescu (2015) in an examination of an organisation (CDCDI) to examine the integration of Romanian employees. The analysis of Iancu et al. (2017) on the factors influencing foreign employment suggests that with the increase in Romanian GDP, industrial employment and foreign investment, the number of emigrants began to decline. It has also been shown that a 1\% increase in unemployment leads to 2.57 emigrants. Similar results were also obtained by Polish researchers (Fogel, 2015; Burrell, 2016).

Labour migration from Poland to Germany is largely dependent on the per capita GDP of Germany and the level of Polish unemployment. The main reason for leaving the Poles abroad is the difference between the economic development of the two countries. In contrast, the flow of Poles to the United Kingdom is determined by institutional factors, primarily the possibility of free movement. At the same time, labour migration from Ukraine to Poland is set by two economic factors: the employment rate of the Ukrainian population (for Ukraine) and the GDP of one Polish employee (in Poland). This means that if Poland's GDP per capita grows, it encourages the Ukrainians to migrate to the neighbouring country, by which employment rates will decrease in Ukraine over the same period.

The move of Slovak citizens to another country is primarily motivated by increasing family income and improving living conditions (Ivanova, 2015; Kollarikova, 2016), as well as the Lithuanians (Ranceva, Rakauskiene, 2015). Lithuanian authors have found that the major obstacles to growth in employment and the resurgence of the economy are the huge socioeconomic disparities in Lithuania.

Older member states have doubled the emigration value of post-socialist countries. This is because of the fact that the latter have a much larger tradition of foreign employment and that the language barriers are smaller. In Austria, 17.4 percent of the total workforce is foreign. Of the total of 615,000 foreign nationals working there, 91,000 are German, which means that every 40th employee came from Germany to Austria. In Central and Eastern European countries, however, emigration seems to be much more spectacular: on the one hand, it is essentially one-way: fewer Westerners come to our region than vice versa. On the other hand, the emigration was previously very low in the region and suddenly gained momentum. However, it is not enough to examine emigration in itself and in absolute terms, as the process is mostly of a temporary nature, that is, some of the individuals are relocating to their homeland over time. Considering this phenomenon, net foreign migration has been declining in several countries. Statistics on emigration typically underestimate the reality. The reason for this is that in most countries they can only track the movement of citizens through the registration and registration of the address or the social security register. However, if someone does not go to work but is employed for family reunification or black jobs, they are not included in these data. It is also characteristic that many people go home every month, do 
not rent their own apartments, so they are not registered abroad (Ruhs, Vargas-Silva, 2014; Macro / Outlook report, July 2017, CEE; Cerna, 2018).

Due to the large number of foreign workers, economic growth in Central and Eastern Europe is pending. One of the reasons for this is that investor companies are struggling with a significant labour shortage, which is detrimental to foreign entrepreneurs. According to surveys, $73 \%$ of Hungarian employers surveyed are struggling with labour shortages. In the case of surveyed companies and other countries, the problem was similar: Bulgaria (36\%), Poland / Czech Republic (35\%) in Slovakia (24\%). Only Romania (7\%) in the EU has achieved an average of $13 \%$ of the countries in the region with regard to the proportion of employers who struggle with labour shortages (Fruchter, Sielewicz, 2017).

According to IMF data, Central and Eastern European emigration reduced the annual GDP of some countries in the region between 1999 and 2014 by $0.6-0.9$ percent. This is the other effect of foreign employment. According to the projections, due to emigration, in Bulgaria, Romania and some Baltic countries, by 2030, GDP per capita will be 3-4 percent lower than it would be without. This will, of course, have a negative impact on the budget of the countries. The biggest concern will be pension expenditure, which accounts for half of social spending in this region of Europe (Fruchter, Sielewicz, 2017, Cerna, 2018).

As a result of this situation, several countries have tried the "Come home" programmes, but they were not effective. Wage increases did not seem to be a good solution either. In Bulgaria and the Baltic countries, for example, in the past five years, wages have increased at a rate exceeding the rate of productivity gains, which may in turn increase the competitiveness of their exports. In other countries immigration was the answer to the challenges of emigration. After a decline in the 1990s, Estonia's population grew in 2015 and 2016 by the arrival of Ukrainian, Russian and Belarusian migrant workers. From the point of view of the economy, however, it does not matter what kind of workforce goes and how it comes in. In Poland, 400,000 Ukrainian workers have been granted residence permits in 2015 as agricultural, construction and household assistants, while 30 percent of outgoing Poles have a tertiary qualification (Macro / Outlook report, July 2017, CEE).

Following the brexit, there can be a huge wave of migration from Great Britain to Eastern Central Europe, which could increase GDP in these countries. A significant part of the previously emigrated individuals is likely to move towards the eastern part of Europe in the near future. The biggest boost to the turn is that before the brexit the pound will weaken, which will devalue the income and savings of British workers. Emigrants can, with their return, remedy the shortage of skilled labour, which was caused by their departure. This may also give new impetus to investment in the region as it converges the economy of the eastern and western part of Europe. The process will be encouraged by the fact that Central and Eastern European countries have changed a lot since the beginning of emigration. The legal environment and the quality of education have improved, Western work culture has become more widespread, and sometimes even governance (Fruchter, Sielewicz, 2017).

\section{Research methodology}

The objective of the research was to get acquainted with the motivation and integration of workers from various Central and Eastern European countries to London. The investigation is primarily exploratory, but it also reveals some cause and effect relationships.

On the basis of the above, a question of research is whether foreign employment is a consequence of a rational decision. On what grounds did people decide to go abroad to work?

On the other hand, what cultural and social capital do foreign workers have and what "networks" can they develop? In addition, what is their mobility capital like? 
In addition, how receptive is society to the immigrant's way of life, habits, self-esteem; how society can appreciate individual achievements and how can individuals find home in this modern world? However, the question arises as to how the different outcomes of integration are influenced by the length of time spent in the host country, the individual characteristics of immigrants (schooling, qualifications, language skills, age, place of birth, social capital) and migration motivations, and structural factors (social and economic structures, solidarity within the ethnic group, family background).

The survey was conducted as a questionnaire in London, in English and Hungarian, which was preceded by a test run. The questionnaire consisted of 4 parts: demographic data, working conditions, current workplace and integration, new life, contained mostly multiplechoice questions. The sample $(\mathrm{n}=307)$ is based on individuals coming from different countries to London who are legally working. The pattern was created through personal relationships, using the "snowball" method, and therefore is not representative. Examining the characteristics of the examined sample with descriptive statistics, the relationship between the examined quality variables was analyzed by a Chi-square test.

\section{Research results and findings}

\section{The socio- demographic characteristics}

The gender distribution of the respondents is almost the same, $51 \%$ for women and $49 \%$ for men. Due to foreign employment, language proficiency and adaptability, younger age groups are more common. The immigrants working in London are essentially young people. The respondents are between 18 and 30 years of age. The lowest share in the sample (10\%) is the youngest (18-20-year-olds), and the 20-30-year-olds split into three-year intervals - more or less evenly - in $30 \%$ of the 21 -23-year-olds, $33 \%$ of the $24-26$-year-olds and $27 \%$ of the 27 30 -year-olds.Foreign workers are less committed to their family ties. In terms of marital status, the data are similar to those of today's young age: half of respondents (50\%) are single, one third live with partners, $12 \%$ married, $7 \%$ engaged and $1 \%$ divorced.

The distribution of the respondents by country of origin shows a colourful picture. The proportion of Hungarians is extremely high (34\%), because a relatively large number of Hungarian respondents have been included in this sample. The country of origin of the respondents is as follows: Polish (11\%), Bulgarian (10\%), Czech (10\%), Slovak (9\%), Romanian (9\%), Latvian (7\%), Lithuanian (5\%), Ukrainian (3\%) and Albanian (2\%) (Figure 1). The graduates have a high level of qualification (two thirds of them with tertiary education): more than one third (38\%) have completed university and more than a quarter (28\%) have completed a college. Nineteen percent have a certificate of secondary education and twelve percent has a professional qualification. Only 3\% of the sample did not go on studying after the primary school (Figure 2). 


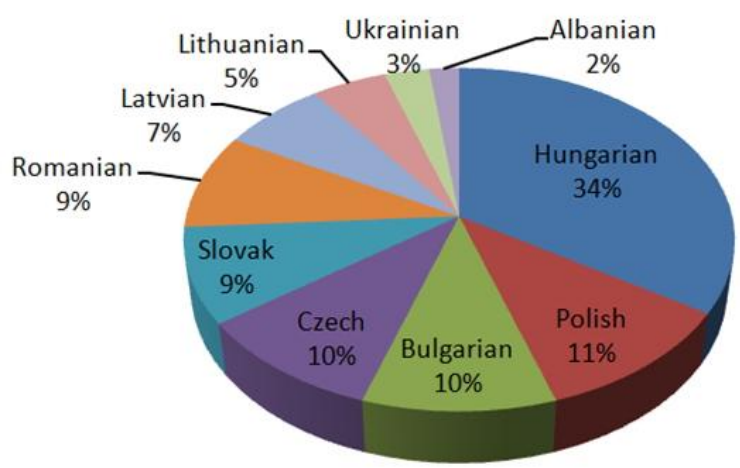

Source: own construction

\section{Figure 1. Distribution of the respondents by country of origin}

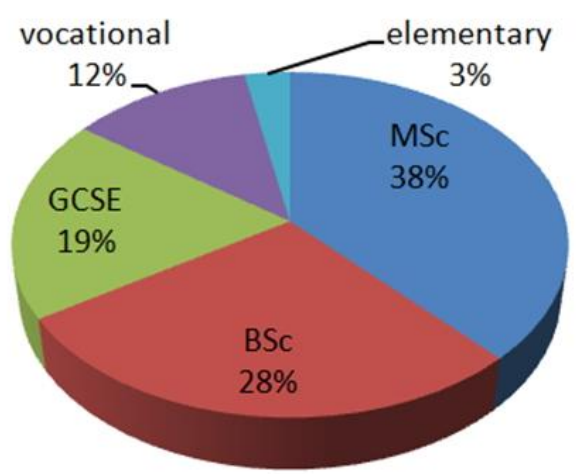

Source: own construction

\section{Figure 2. Distribution of the respondents by qualification}

The questionnaire also asked about the childhood circumstances of the respondents, as this factor may be decisive in deciding whether or not to move from a previous home to a more or more developed city. Foreign workers are characterized by urban origin. Most respondents are from (small) towns (41\%), one-fifth (20-20\%, respectively), from cities and the capital city while $17 \%$ of respondents grew up in a village and $2 \%$ in rural areas. Individual childhood family circumstances may also influence migration. The participants of the sample are lucky in this regard, because almost all of them (83\%) were raised together by their parents, one parent (16\%) and one (1) by grandparents. In addition to the fact that the education of the parents has an impact on the education of the growing child, may also affect the decision to work abroad. Most respondents come from an intellectual family: most of them are college (29\%) and university graduates (27\%). One quarter $(23 \%)$ of the sample have parents with intermediate level vocational qualifications and $13 \%$ of the individuals have parents with a certificate of secondary education. The parents of seven percent of the sample completed primary school and in the case of 1\% the parents dropped out without any qualification.

The foreign workers participating in the survey represent nearly equal gender ratios, mostly young people, of urban origin, from intellectual parents who have been raised in the family, are basically single or live in relationship.

\section{Characteristics of employment}

The level of motivation for foreign employment was very colourful, but essentially distribution is the same (one third) between economic, family and work-related motives. The most frequently occurring (34\%) reasons were economic (better salaries), which also was a leading factor in previous research. This was followed by nearly $31 \%$ of work-related motives, including "gaining experience" (14\%), "finding work at home" (10\%); the "it makes my resume look attractive" (7\%). In almost the same proportion (30\%), personal reasons played a role in the decision (adventure 14\%, learning 10\%, friends 6\%), and other reasons with 5\% (tourist attractiveness with 3\% and unfair treatment at previous workplace with 2\%) (Figure 3).

Basically, it is apparent that the driving force is based on economic considerations, but experience gains, which can characterize domestic career opportunities, as well as the adventurous desire that are more and more characteristic of the young age group, are very significant. 
According to the length of working abroad, most of the respondents (42\%) worked for 1 to 3 years in London. The second highest value was equal to those who came close to 1 year and 3-5 years: 20-20\%., respectively. This was followed by the number of arrivals a few months ago (16\%), followed by $2 \%$ of respondents staying over 5 years abroad. Concerning the planned duration of staying, $40 \%$ are still uncertain as to how long they want to stay, about one in four (24\%) of the respondents do not plan to return home. The proportion of those planning for one to five years $(16 \%)$ is also outstanding, and those who intend to stay abroad for long or short term: $15 \%$ of all respondents have scheduled less than 1 year and 5\% for longer than 5 years (Figure 4).

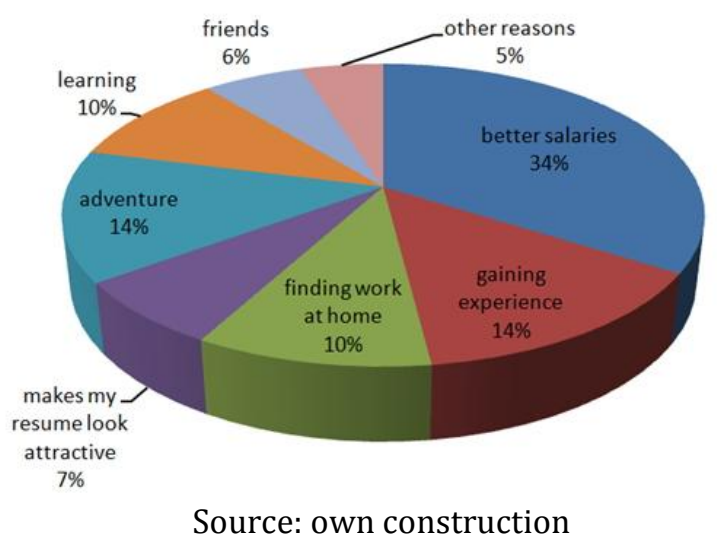

Figure 3. Motivation for foreign employment

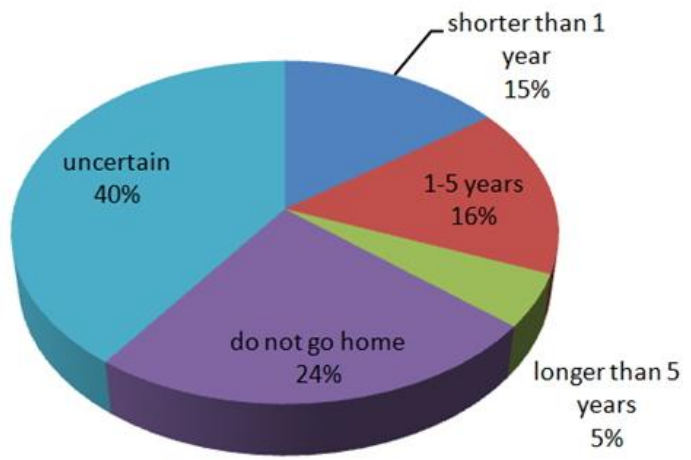

Source: own construction

\section{Figure 4. Breakdown of the sample by their planned stay in London}

The reasons for a longer stay in London were an open question, indicating more options. The most common responses were the following: there were no opportunities in the home of the participants, they did not have a vision at home, the political circumstances are bad, they are looking for a better life in London, they live more comfortably. Many people mentioned the city's beauty and multicultural atmosphere as an attractive factor and the fact that they founded a family. Those who would definitely want to return to their home country justified their decisions by the fact that they do not like weather, their families and friends are in their homeland, London is overcrowded, loud, rushing, expensive, and originally, they just planned a short visit. Among the respondents, there were those who did not want to either go home or stay in London: "I want to try out more countries", "if there is better opportunity elsewhere, I will go for it."

The people concerned were basically informed through personal contacts about the job opportunities abroad - to a third of them the workplace was recommended by a friend (38\%). But with almost the same proportion comes the category of luck seekers (37\%) without any preliminary information. The third place was those who came through advertising (whether online or in press) with $18 \%$, and through London and home job advertisers, by $7 \%$. Two thirds of the participants in the study, therefore, were conscious job seekers, while one third of them were randomly placed. The difficulty of finding a job in London was scored on a scale of 3 degrees. The majority, that is, $42 \%$ of the average, 39\% said it was easier to find work than average, with the remaining 19\% judging it to be more difficult than average. One question was whether respondents had already worked in their home country. Two thirds of the respondents (65\%) worked in their country, 29\% completed their studies and did not work, so they were absolute career starters, and only $6 \%$ reported being unemployed earlier. 
The motivation of respondents is not characteristic of foreign employment, but the high proportion of consciousness, in accordance with the theory of action, was in any case a result of a rational decision.

\section{The features of the current workplace}

Less than one fifth (19\%) of the respondents has a position of their original qualification in London, while the remaining 81\% are working in another area. One-quarter of them (27\%) work at the level of their qualification, half the respondents (51\%) are below on level and two-thirds (22\%) below two levels. The latter category includes both highly educated and skilled or those doing semi-skilled work. At the time of the questioning, half of the respondents (51\%) indicated catering / tourism as occupational area. Based on the answers received, there is a significant number of other services (19\%) and the share of food industry employees (12\%). The number of those involved in business administration (4\%), education, trade and marketing, healthcare, social services, information technology, transport and agriculture (2-2\%, respectively) was close to each other. The above proportions can partly be explained by the fact that in London - being a world capital - mass tourism is gaining momentum, in which employers are willing to employ foreign labour, similarly to food industry that gained the third place. The daily working time worked at the level of the domestic population, slightly increasing for all respondents: the number of those working in 6-8 hours (from 31\% to 33\%) and 8 to 12 hours (from 33\% to 35\%) nearly equals. The proportion of people working for up to 6 hours a day increased from 29\% to 32\%, while there was no one more than 12 hours a day in London. The domestic rate for this latter category was $7 \%$. The vast majority of respondents (79\%) enjoy their work at the current workplace and the remaining $21 \%$ claim the opposite.

In light of this, the study also highlighted where to work better according to experiences. Three-quarters (75\%) of respondents said it was better to work in London, $17 \%$ said their country, while the remaining 8\% mentioned a different city, among which are Toronto, Monaco, Zurich, and the United States and Australia are also named as countries. Analysing financial circumstances and opportunities, respondents also responded if they are earning more abroad than in their home country (How much?). Comparison was generally applicable to payments available abroad compared to home / country payments. Nearly half of the respondents $(45 \%)$ said they were earning more than twice their home salary in London. One-fourth $(24 \%)$ roughly the double, one-fifth $(19 \%)$ a little more in London than in their home country. Four percent of respondents are earning as much as they would be earning in their country of origin and 8\% replied that they are earning less in the capital city. Overall, $88 \%$ of respondents thought that they would receive more salary in London than in their homeland.

We can say that the employees involved in the study work mainly in the field of hospitality and tourism (but this may also be a distortion of the sample), not in their own profession, at a lower level than their degree of qualification. Everyone works more than at home, and they are earning more. They are basically feeling better at the London workplace than at home and enjoying their work.

\section{Integration, segregation}

One factor affecting integration is the frequency and extent of meeting foreign culture. More than half of the respondents (54\%) are constantly encountering foreign cultures, onefifth $(22 \%)$ often. Subsequently, the responses share the same proportion $(10 \%)$ between 
"just when I work" and "very rarely". "Just for fun" and those who "hardly ever" are faced with differences, accounted for 3\% and 1\% of the surveyed sample, respectively. One third (34\%) do not seek to obtain British citizenship, one fifth of them are insecure (22\%), the rest of the respondents (44\%) already have or are in the process. The main motivations of citizenship are marriage, children, EU passport, which provides them with free flow of labour within the Union.

London, which stands as the centre of multiculturalism, functions as a home to countless representatives of many nationalities. In the questionnaire, it was possible for the respondents to characterize the people in London (i.e. not the British, but rather the colour crowd) in 3 words. The responses received are divided into three groups: only positive words, then who only described the group with negative terms and who have mixed statements. More than half of the respondents (56\%) used only positive words for the characterization of Londoners, one third (30\%) mixed emotional terms, and 14\% responded negatively. Interestingly, the most common positive words were helpful, gentle, polite, patient, friendly, open, accepting expressions. The most common negative features were busy, rushing, drunk, "party-animal", "bang-mad", brittle, bad-humorous, lazy, messy words. The questionnaire also enquired whether the interviewees had or had previously had foreign friends. Half of the respondents (51\%) already had international relations before the time they left off. In a much lower proportion (42\%) are those who made foreign friends after leaving. The lowest proportion $(7 \%)$ was made up by the category of having non-foreign friends.

The factor influencing emotional integration is how immigrant workers feel at home in the environment they live and work. Two-thirds of respondents (65\%) are living in London and do not feel like strangers, one-fifth (21\%) said they are already at home in London, they call it home and 14\% feel totally out of touch (Figure 5). Thus, it seemed logical to ask how those concerned feel abroad or, rather, they feel to belong to their own original nation. Fifty five percent of the respondents said they had retained their original nationality and was associated with a new sense of consciousness in London. So, they are still tied to their original culture and nation, but adapting to the prevailing circumstances, their personality has been enriched with a new colour, which can be called "London consciousness". According to them, they have already abandoned, renounced their identity in the previous phase of their lives, and replaced (by their own admission) a new self-consciousness of London, which completely eliminates the former. To a greater extent, one third (31\%) of the respondents said they did not have a change of identity in their case, they only felt as belonging to their original nation, not a little Londoner. Finally, 1\% did not respond. Nearly a quarter of the respondents (26\%) visits home once a half year, almost the same $(24 \%)$ on a monthly basis, followed by $22 \%$ who come home rarely than once a year and $18 \%$ return once a year. Five percent never visits their homeland, followed by a frequent group of travellers who come home frequently (3\%) and weekly (2\%) (Figure 6). 


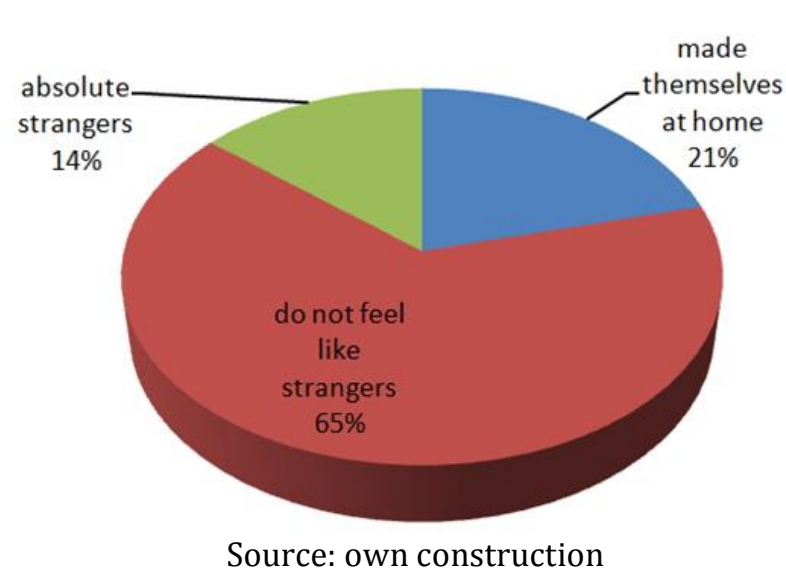

Figure 5. Breakdown of the sample by how they feel in London

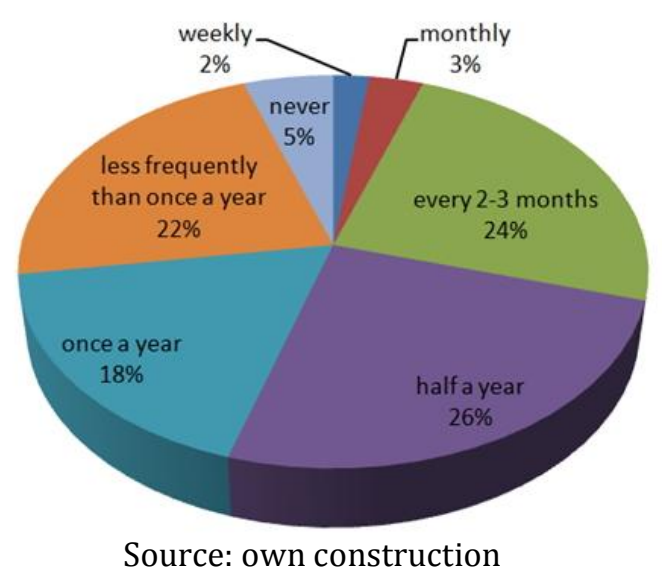

Figure 6. Breakdown of the sample
by the frequency of their visiting home

For those arriving from distant countries to London, long-term employment can make it difficult to keep in contact with friends who are left at home (family or friends). The fact of leaving their loved ones and the strength of the emotional bond they feel may determine or at least influence the duration of the stay and the date of return. In the case of questioned people, the next question was: "How do you keep in touch with your loved ones (friends and family)?" The most commonly used internet connection is with young people living in London (59\%) and the second most commonly used method (36\%) is the phone. Interestingly enough, the group of frequent and unrelated people (2-2\%, respectively) achieved the same ratio. The latter can be explained by the distance, possibly the different time zone, the new lifestyle, or the initial weakness of the relationship, due to the weakening of the emotional attachment. One percent keeps in touch in other ways: paper-based, traditional mails.

It is often seen in the case of people working abroad for a long time, that they are "counted" abroad, in London as foreigners and because of their new lifestyle and living place at home, they are also regarded as foreigners in their homeland. The question arises whether this situation is causing conflict in the lives of those affected. Twelve percent of the respondents said that this was not a real problem at all and they never experienced any conflicts. The largest proportion, 58\%, did not claim it a real problem, either, as they never had a conflict. Twenty-two percent felt uncomfortable, but there was no conflict with the others, $7 \%$ regarded it as a minor problem and 1\% said it was often uncomfortable. The problem is therefore not significant in most cases (70\%).

Three quarters of respondents often encounter another culture, all of them speak the language at some level, and citizenship is also required by three-quarters. Half of the respondents visit their home country several times a year, one-third of them once a year.

\section{Correlations}

There was a strong correlation between the analysis of the time spent abroad and the planned duration. The Chi-square test (which means that if the Chi-square test is below 0.05, there is a significant correlation between the data) showed 0,000 sig correlation. According to the respondents in the sample, those who have been working for more than 1 year in London $(20.9 \%)$ are considerably likely (37.3\%) to return to their homeland. While those who have been working for less than half a year in London are planning to return home $(6.2 \%)$ (reverse question), similarly to the other end. The less time one spends in London the more likely 
(29.2\%) he plans to return home within 1 year than those who have been working for more than a year $(1.7 \%)$ (the average value here was $13.1 \%)$.

The expectations were justified by the correlation analysis in which the relationship between the amount of London wages and the length of working hours was revealed. The Chisquare test did not surprisingly show a very strong correlation between the two factors $(\mathrm{p}=$ $0.004 \mathrm{sig})$. Based on these, it is clear that who earned more than the average in London (88\%) were those who spent more time working - 8 or more hours $(94.7 \%)$. Who admitted earning less than their previous home earnings were those who spent fewer hours (0-6 hours) working daily in London (60\%).

The duration of working abroad is related to the fact whether the persons concerned had a foreign friend during the pre-departure period. The cross-table analysis showed that there is a significant correlation between the answers, since the Chi-square test was $p=0.029$ sig. For those who did not have a foreign friend before or after leaving, correlation with the residence time $(56.2 \%)$ is greater than the average $(24.1 \%)$. A short residence time (0-0.5 years) was the least characteristic of those who had such friends before leaving (19.2\%). In the latter case, a greater than average correlation was diagnosed in the case of residence time of 0.5-1 years and 1 year. However, there was a greater correlation (46.4\%) in the case of those staying for more than one year and having made such friends after relocation (average: 42.1\%). All in all, it can be said that the duration of foreign employment changes depending on whether the person has a foreign friend. More importantly, the time spent there is also related to the fact that immigrants have made foreign friends after moving.

Considering the frequency of home visits depending on the length of work in London, the Chi-square test $(\mathrm{p}=0.002 \mathrm{sig})$ showed a strong correlation. The longer the time spent in London is, the more affected the worker concerned $(37.3 \%)$ than the average $(22.1 \%)$ in coming home more rarely than once a year. While concerning the respondents in London for less than half a year, it is more likely (34\%) that they visit home within a few months than the average $(25.3 \%)$. The following correlation is related to the change of identity and the enjoyment of work. The Chi-square test showed a markedly strong correlation ( $p=0.007 \mathrm{sig})$. That is, if a migrant worker enjoys his job, then he is more likely to feel $(60.7 \%)$ than the average $(56.1 \%)$ that he is a Londoner / or of London and his original (mix) nationality. While the person does not enjoy the job with a higher probability (41.9\%), he or she will feel more of an original nationality than the average (36.5\%) or none $(19.4 \%)$ (the average is $7.4 \%)$.

Considering the intention to resettle in London, there was a significant correlation with the change in identity theorem ( $p=0.015 \mathrm{sig}$ ). So, according to the participants in the sample, it is logical to think that those in London or London feel more like settling in London (62.2\%) than the average (51.7\%) or individuals who feel like being of native nationality $(37 \%)$ or do not belong to any of the groups (45.5\%).

In summary, respondents do not show great and significant differences in the country of origin, along different socio-demographic variables, migration motivation, preliminary information, labor market integration and some dimensions of social inclusion. These test data confirm the importance of mobility and cultural capital for working abroad.

Recognition theory seems to be justified in respect of work performance but recognizing the outcome of work is a decisive factor in the success of the job market.

As a result of the identification integration, according to Bodó's theory, most of them feel at home in London, have dual or only British consciousness in London.

Almost all of them have made a positive remark on their lifestyle in London and foreign friends, which are in turn based on the theory of mobility capital and, on the other hand, social capital. 


\section{Conclusions}

From the multifaceted concept of integration, the paper deals with some of the key aspects of foreigners' integration into the labour market and society. The purpose of our exploratory research was to get acquainted with the socio-demographic characteristics, motivations, workplace conditions and social participation of foreign workers from different Central and Eastern European countries to London.

The main findings and conclusions of the study can be summarized as follows:

- Respondents do not show significant and significant deviations along the variables according to country of origin.

- The foreign employers participating in the survey represent nearly equal gender ratios, they are predominantly single or in relationship; young people of urban origin, intellectual children of intellectual parents who have been raised in a family.

- The socio-demographic characteristics did not correlate with other variables.

- The motivations of working abroad are not distinctive, but the high proportion of consciousness, in accordance with the theory of action, has certainly emerged as a result of a rational decision.

- The wealth of social capital is essential for the integration of immigrants into society and the labour market.

- The analysis has shown a strong correlation between the time spent abroad and the planned duration.

- The duration of working abroad is related to the fact whether the persons concerned had a foreign friend during the pre-departure period.

- Employees participating in the survey work mainly in the field of hospitality and tourism, not in their own profession, at a level lower than their qualifications.

- Everyone works more than in his home country, but they are earning more.

- Those earn more in London who spend 8 or more hours a day working.

- Respondents feel better at the London workplace than at home and enjoy their work.

- Generally speaking, social integration has been achieved in the sample of the study.

- Three quarters of respondents often encounter another culture, all speak the language at some level, citizenship is also required by three-quarters.

- Almost everyone was positive about their lifestyle in London and their foreign friends.

- In the case of identification integration, most of them feel at home in London, have dual or only "mono- consciousness" in London.

- Half of the respondents visit their home country several times a year, one third each year.

- The longer the time spent in London is, the more affected the worker is concerned with visiting home less frequently than once a year.

- If a foreign worker enjoys his job, he will be more likely to feel like a Londoner / or of London and his original (mix) nationality.

- The more they feel as a Londoner or as a Londoner, as well, the chances of settling in London are higher.

- The Chi-square test did not show any significant correlation with the other variables.

Based on the conclusions, the following process seems to emerge: if an individual has a foreign friend, they will stay away from their homeland for a long time; the longer they are staying, the less frequent they visit home. If they enjoy their work (which does not depend on education or profession) they feel more and more like a Londoner, and if they feel so, they are going to settle down. 
Considering the social integration in four dimensions, it can be concluded that integration in all areas of the analysed population was completed as responses were given in a higher ratio by two-thirds. The highest value was represented by having foreign friends $(93 \%)$ and the positive opinion of the people in London (86\%). Giving up their own national identity was achieved the least. Social integration is the strongest, followed by an equal share of structural and cultural integration, and least of all, the identification of foreign workers. In general, it can be stated that social integration was achieved to a certain extent in the case of the examined sample.

Based on our research results, transnational migration can be called a process represented by a large majority of foreign workers coming to London from various Central and Eastern European countries, as their connection to both countries has evolved. The question of the future is how long the transnational status can be extended and how long it can be sustained in the course of the individual's life. Professionals know that talents and good professional skills are essential for innovation and development in knowledge-intensive economies. Recent labour migration can be seen as a relief in the short term in the labour market, but at the same time, in the long run, the region's economic success is threatened.

Migration for work is a phenomenon where people go away from their place of residence very often to another country. The study deals with the exploration of the three basic characteristics of globalization - the migration motivations of the foreign workers, their labour market characteristics and the degree of their social integration. Our research focusses on the employment of young and highly skilled professionals from Central and Eastern Europe in London and the factors influencing the success of social inclusion across different dimensions. The review aims at detail and thoroughness, but it is not complete.

The novelty of the study lies in the composition of the sample on the one hand, and on the other hand, the study mainly focuses on the labour market. The conclusions of the study provide an adequate framework for the development of a rational economic policy program, which is the basis for future development, for the conscious development of the future of our region.

\section{References}

1. Andor, L. (2014) Munkaerő-mobilitás az EU-bővítés után. Közgazdasági Szemle, Vol. 61, No. 4:363372.

2. Bodó, J. (2016) Határátlépések, térbeélések. Migránsok a transznacionális térben. Iskolakultúra, Vol. 26, No. 1: 20-30.

3. Burrell, K. (2016) Polish Migration to the UK in the 'New' European Union after 2004. London Routledge. 260 p.

4. Cerna, L. (2018) European High-Skilled Migration Policy. High-Skilled Migration: Drivers and Policies, 87.

5. Colliers International Prague (2017) Labour force „boomerang”. CEE Real Estate. Macro Outlock Report Prague [online] [accessed 21 May 2018]. Available from internet: <http://www.colliers.com/en-gb//media/Files/EMEA/emea/research/CEE/Colliers_CEE_Boomerang-2017>.

6. Éber, M. Á. (2008) Túl az élménytársadalmon. Avagy az élménytársadalom másfél évtizede. Szociológiai Szemle, Vol. 18, No. 1: 78-105.

7. Éber, M. Á. (2016) Kritika és korrekció. Szociológiai Szemle, Vol. 26, No. 2: 29-43.

8. Eurostat (2016) Migration and migrant population statistics. [online] [accessed 20 May 2018]. Available from internet: <http://ec.europa.eu/eurostat/statistics-explained/index.php/ Migration_and_migrant_population_statistics>.

9. Farkas, A. (2014) A politikai manipuláció: Egy elmélet kifejtése és történetének jellemzői, Budapest, Prema Consulting Bt, 50-55.

10. Farkas, Z. (2013) Az érdekérvényesítés mértéke és a társadalmi állapot meghatározottsága. Valóság. Vol. 56. No 3: 13-26. 
11. Fogel, K. (2015). The multistage nature of labour migration from Eastern and Central Europe (experience of Ukraine, Poland, United Kingdom and Germany during the 2002-2011 period). Eastern Journal of European Studies, Vol. 6, No. 2: 55-81.

12. Fruchter, D., Sielewicz, G. (2017) Labour shortages in Central and Eastern Europe countries: a growing concern for businesses, COFACE Economic Publications. [online] [accessed 10 May 2018]. Available from internet: <http://www.coface.com/News-Publications/Publications/Labour-shortages-in-Central-andEastern-Europe-countries-a-growing-concern-for-businesses>

13. Hárs, Á. (2016) Elvándorlás, bevándorlás és a magyar munkaerőpiac. Jelenségek, hatások, lehetőségek. [In: Kolosi T., Tóth I. Gy. (ed.) (2016) Társadalmi Riport.] TÁRKI, 262 p.

14. Havrancsik, D. (2016) Fenomenológia és társadalomtudomány. Alfred Schütz protoszociológiája. Különbség Vol. 16, No 1: 115-129.

15. Iancu, N., Badulescu, A., Urziceanu, R. M., Iancu, E. A., Simut, R. (2017) The use of the gravity model in forecasting the flows of emigrants in EU countries. Technological and Economic Development of Economy, Vol. 23, No 2: 392-409.

16. Ivanová, E. (2015) Social and economic development of regions of the Slovak Republic. Institutional framework for the functioning of the economy in the context of transformation. p. 12-20 [online] [accessed 21 May 2018]. Available from internet: <http://conf.at.ua/25-31.05.2015.pdf\#page=12>.

17. Kolláriková, P. (2016) International Labour Migration. A Present-Day Phenomenon Using the Example of Slovakia. Ethnologia Actualis, Vol. 16, No. 1: 30-40.

18. Lăzărescu, L., Panait A., Iordache A., Dimulescu V., Antofi, M. (2015) Între discriminare, abuz si exploatare. Asocia? ?ia Română pentru Promovarea Sănătă ?ii, Raport de Cercetare, 120 p.

19. Murphy-Lejeun, E. (2003) Student Mobility and Narrative in Europe: The New Strangers. Routledge Studies in Anthropology ${ }_{\llcorner}$Routledge, $288 \mathrm{p}$.

20. Portes A., Böröcz J. (1989) Contemporary Immigration: Theoretical Perspectives on Its Determinants and Modes of Incorporation. International Migration Review, Vol. 23, No. 3: 606-630.

21. Ranceva O., Rakauskiene O. G. (2014) Youth unemployment and emigration trends. Intellectual Economics, Vol. 8, No. 1: 165-177.

22. Rózsa, E. (2011) Az elismerés a kortárs filozófia kurrens témája és a korszerű társadalomelmélet kutatási paradigmája, Magyar Tudomány, Vol. 172, No. 2: 2010-2015.

23. Ruhs M., Vargas-Silva C. (2014) The labour market effects of immigration. Migration Observatory Briefing, University of Oxford. [online] [accessed 13 April 2018]. Available from internet: <http://www.migrationobservatory.ox.ac.uk/wp-content/uploads/2016/04/Briefing-

Labour_Market_Effects_of_Immigration.pdf>.

24. Schütz, A. (1984) „Az idegen”. [In: Hernádi Miklós (ed) A fenomenológia a társadalomtudományban, Budapest, Gondolat, p. 405-413.]

25. Sík, E. (2012) A migráció szociológiája. Budapest: ELTE TáTK. 144 p.

26. Stone, W., Hughes, J. (2002) Measuring social capital: towards a standardised approach. [online] [accessed 21 May 2018]. Available from internet: <http://citeseerx.ist.psu.edu/ viewdoc/download?doi=10.1.1.568.5896\&rep=rep1\&type=pdf.> 